\title{
Eradicating Income Inequality in Lower Middle-Income Countries
}

\author{
Tangguh Pratysto ${ }^{1 *}$, Ingrid Panjaitan ${ }^{2}$ \\ ${ }^{1}$ Department of Accounting, Faculty of Economic and Business, Universitas 17 Agustus 1945 \\ email: tangguhpratysto@yahoo.com
}

Recieved: July 2019 | Revised: September 2019 | Accepted: November 2019

\begin{abstract}
Studying the distribution of income is an important issue to know what factors cause income distribution more equitable, what factors can be the key to resolving the problem of income inequality, and shortening the distance between the poor and the rich. This paper examines the relationship between human capital, inflation rate, unemployment rate, physical capital, fiscal expenditure, gross domestic product growth, and urbanization on income inequality in 52 Lower Middle-Income Countries throughout 1990-2014. The authors estimate the impact of seven independent variables on income inequality as a dependent using Prais-Winsten with the robust model over the period 1990-2014 at 52 Lower Middle-Income Countries. The results indicate an increase in human capital (gross school enrollment tertiary) can make the income distribution more even in the long run. The writers conclude that increases in human capital can reduce the Gini coefficient and hence make income distribution fairer.
\end{abstract}

Keywords: Tertiary School Enrollment Tertiary; Income Inequality; Gini coefficient; Human Capital; Income Distribution

JEL classification: I24

How to Cite: Pratysto, T., \& Panjaitan, I. (2019). Eradicating Income Inequality in Lower MiddleIncome Countries. Jurnal Ekonomi Pembangunan: Kajian Masalah Ekonomi dan Pembangunan, 20(2). 222-231 doi:https://doi.org/10.23917/jep.v20i2.8517

DOI: https://doi.org/10.23917/jep.v20i2.8517

\section{Introduction}

Studying income distribution is a critical issue to know what factors can make a fairer income distribution and what factors can make it unfair, is an essential key to resolving the inequality problem and shortening inequality between poor and rich (Shahpari \& Davoudi, 2014). Today the world faces inequality as significant economic and social problems. The disparity consists of three economic imbalances, namely wealth disparity, income disparity, and consumption disparity. However, income inequality is the most commonly used metric. The income inequality analysis consists of studying income distribution disparity between countries or social groups (Mihnenoka \& Senfelde, 2015).

The struggle for poverty and social exclusion begins with an inequality analysis in society; and is continued by involving governments, policymakers, and communities. The income inequality issue is critical because economic resource distribution will have a direct impact on social inclusion and poverty reduction. Around the world, income inequality increases between countries or within the state itself as a consequence of the globalization process (Militaru \& Stanila, 2015). 
Stiglitz (2015) argues that the rise in inequalities in most countries can explain through a process which money spend on those who already have so much money that they cannot pay it all. Thus, he claims an increase in income inequality is the main reason causing the economic and financial crisis. Stiglitz (2015) says too vast disparity will lead to a perception of an unjust system that extends to mistrust of government.

The uneven distribution of household or individual income from various participants in the economy is called income inequality (Ling, Osman, Muhammad, Yeng, \& Jin, 2016). Many researchers are trying to investigate the reasons for growing income inequality from multiple perspectives (Zhang \& Chen, 2015). The income inequality is the core of economic inequality (Militaru \& Stanila, 2015). When analyzing inequality, it is essential to define the income concept like income before transfer and tax, disposable income, market income (Smeeding \& Weinberg, 2001). Economic development can lead to an increase in income inequality, while fiscal and social policies (through tax and social) can offset the effects of economic growth. The income inequality analysis base on household income distribution. Primarily from household member income. The other income sources include financial income (rent, dividends, interest income) and income from social transfers (benefits, pensions, unemployment benefits) (Militaru \& Stanila, 2015).

The income disparity is closely related to economic efficiency in resource use, which is limited based on economic efficiency criteria. While this may benefit some people, it may also harm some people (Militaru \& Stanila, 2015). In addition to any community, the inequality level cannot avoid, but it is also necessary for healthy economic functioning (Welch, 1999). Even if inequality is not a problem itself, the causes and consequences of income inequalities should be considered, analyzed, and mitigated, such as poverty, social exclusion, crime, life expectancy, and health (Nolan, Salverda, \& Smeeding, 2012). High levels of inequality could impede economic growth. Berg and Ostry (2011) argue that economic inequality may strengthen crisis effects; this may lead to political instability, which may hinder investment and difficult to avoid.

Although a certain degree of inequality is an integral part of market economy efficient functioning (Chaudhuri \& Ravallion, 2007), too large an inequality could be harmful to growth. The first significant theoretical studies on economic disparities are Muellbauer and Atkinson (1976), while the pioneer income inequality was (Kuznets, 1955) and (Mincer, 1958). Kuznets promotes the idea between economic development and income inequality; there is a relationship that forms an inverted U curve. This relationship has been the focus of many researchers in the past, and their findings indicate that this issue is still unfinished (Bourguignon \& Morrisson, 1998; Ravallion, 2004; Ravallion \& Chen, 2003). As other variables than economic development have a strong influence on income inequality, such as demographic, social, and cultural factors (Checchi, 2004).

From the reversed $U$ curve hypothesis (Kuznets, 1955), throughout the country's development, there is a natural cycle of economic inequality that increases inequality. Then declines after a certain level of average income are achieved. Therefore, another important variable affecting income distribution is GDP. Based on Kuznet's "reverse hypothesis," states that income growth will initially increase the inequalities, mainly due to investment and human capital from high-income groups). Begin to decline when investment returns are reducing, and migration takes place (Wroblowský \& Yin, 2016). Bagliano and Bertola (2005), Qin et al. (2009) examined the inequality effects on economic growth and found a negative relationship. Chen (2010) investigated the relationship between growth and inequalities in both directions. He discovered that reducing inequality effect is different in the short and long term; the growth effect on inequality is equally negative regardless of time duration. Many studies conclude that growth affects inequality negatively, in the long run, the government should 
try to reform it, though results will emerge in the future. GDP growth, followed by increased disposable income and living standards, will be accompanied by significant changes in income and wealth disparities (Wroblowský \& Yin, 2016). Otherwise, Lundberg and Squire (2003) conclude that there is no direct relationship between growth and inequality.

In a study, Kuznets (1955)explained the emergence of the industry leads to a situation where households are beginning to migrate from a weak agricultural sector, characterized by relatively small income inequality, to a wealthier industrial area, where income distribution is less equitable. During the early stages of transition when the majority of the population still works in the weak agricultural sector. While some workers have moved to more prosperous cities in the industrial area, resulting in growing inequalities. In the study of World Bank economist team Bussolo, De Hoyos, Medvedev, and van der Mensbrugghe (2010) predicts evolution of global inequality by 2030 , the economist team use Kuznets' assumptions about population migration from agriculture to industry with increasing disparities in early stages of industrialization and reduced inequalities in final stages of manufacturing.

Unemployment and inflation are other important variables, which could change the income distribution in various research studies as the main reason for income inequality (Blinder \& Esaki, 1978; Buse, 1982; Nolan, 1986). It knows that Gini coefficients are higher during periods of high unemployment and inflation (Shahpari \& Davoudi, 2014).

Education is an essential factor in human development because the school will increase a person's capacity to acquire knowledge and professional skills that will improve the quality of life, as well as contribute to economic growth(Kudasheva, Kunitsa, \& Mukhamediyev, 2015). Studies in several countries have proved that the relationship between education and income inequality level (Castello \& Domenech, 2002; Coleman, 1968; De Gregorio \& Lee, 2002; Heckman, 2005). The studied domestic and international aspects of socio-economic inequalities in Russian living standards, so providing educational accessibility is an important indicator and factor in income distribution inequality. The main ways of raising incomes and reducing inequalities are by increasing access to vocational education in the population. A higher education level leads to an increase in human potential and labor qualifications development, such as career development (Kudasheva et al., 2015).

Consequently, an increase in the education level contributes to income growth. On the other end of the spectrum, low-income standards following by a lack of access to quality education: the poor cannot raise the level of knowledge and children in their families. Due to the low education level and skills eliminate the opportunity to earn money and have higher incomes. Such a "poverty vicious cycle" only exacerbates income inequality and access to education, so income inequality affects educational inequality and vice versa (Kudasheva et al., 2015). Kudasheva et al. (2015) conclude that access to education is the most effective way to reduce inequalities.

Based on research from OECD (2013), since 1980, the main reason for increasing income inequality in labor is stable growth in demand for high-skilled workers in high-tech industries. This demand is the reason for wage growth for those with professional education, relevant knowledge, and skills to work in the high-tech information communication sector. As a result, wage differences between highly skilled and lowskilled workers are widening, as growth in labor income inequalities (Kudasheva et al., 2015).

Capital profit helped better distribution and concluded that capital \& labor are complementary factors of production. Therefore, an increase in capital accumulation will follow by the rise in demand for work and make the level of employment and wages more than ever, resulting in more equitable income distribution. Then the government can invest this accumulation by investing in rural areas that can be enjoyed by the community and make the income inequality lower (Shahpari \& Davoudi, 2014). 
Based on Zhang and Chen (2015), in the long run, fiscal expenditure has an opposite effect on income inequality, thus indicating fiscal spending minimizes revenue inequality, and this is consistent with economic reality. Because for urban and rural communities in the country can benefit from the multiplier effect by public investment.

The novelty of this research is to study income inequality in 52 lower-middle-income countries in the period 1990-2014. This study uses a longterm period of 25 years; the goal is that in the long run, countries lower-middle-income countries can reduce income inequality. These countries are still developing countries that need equality of income so that their country's politics are stable in the process of becoming a developed country. This study adopts various previous research models to prove that all of these models can reduce income inequality. But for the novelty of the research, researchers use new proxies to represent new models that can reduce income inequality. Other research related to this research mostly only studies income inequality in one country. Fakthong (2012) analyzes inequality income in Thailand in the period 2000 - 2009. Then, Shahpari \& Davoudi (2014) explain equality of income in Iran over the period 1969-2007. Mihnenoka \& Senfelde (2015) in the European Union in 2008-2012. Next, Militaru \& Stanila (2015) explain income disparity in Romania and Kudasheva et al. (2015) in Kazakhstan. After that, Han, Zhao, and Zhang (2016), Wroblowský \& Yin (2016) study income inequality in China and Ling et al. (2016) in Malaysia.

\section{Research Method}

The purpose of this article is to proof of some crucial variables that affect income inequality. This income inequality equation model adopts models from (Shahpari \& Davoudi, 2014)to be as follows:

$$
\begin{aligned}
& \text { Ln Income Inequality }_{i t} \\
& \qquad \begin{array}{l}
=\alpha_{0}+\alpha_{1} \text { Unemployment }_{i t}+\alpha_{2} \text { Human Capital }_{i t}+\alpha_{3} \text { Inflation }_{i t} \\
+\alpha_{4} \text { Physical Capital }_{i t}+\alpha_{5} \text { Urbanization }_{i t}+\alpha_{6} \text { GDP Growth }_{i t} \\
\\
+\alpha_{7} \text { Fiscal Expenditure }_{i t}+\varepsilon_{i t}
\end{array}
\end{aligned}
$$

The research observation of time and place is over period 1990-2014 at 52 Lower Middle Income Countries (Armenia, Bangladesh, Bhutan, Bolivia, Cabo Verde, Cambodia, Cameroon Congo Rep., Cote d'Ivoire, Djibouti, Egypt Arab Rep., El Salvador, Ghana, Guatemala, Honduras, India, Indonesia, Kenya, Kiribati, Kosovo, Kyrgyz Republic, Lao PDR, Lesotho, Mauritania, Micronesia Fed. Sts., Moldova, Mongolia, Morocco, Myanmar, Nicaragua, Nigeria, Pakistan, Papua New Guinea, Philippines, Samoa, Sao Tome and Principe, Solomon Island, Sri Lanka, Sudan, Swaziland, Syrian Arab Republic, Tajikistan, Timor-Leste, Tonga, Tunisia, Ukraine, Uzbekistan, Vanuatu, Vietnam, West Bank and Gaza, Yemen Rep., and Zambia).

The following is an explanation of the dependent and independent operational variables used in this study. The Gini coefficient is used to measure income inequality. So the Gini 0 coefficient represents perfect equality, where means everyone has the same income, while index 1 implies ideal inequality where means the entire profit is in one individual.

In most empirical works, the Gini coefficient using as an income inequality measurement (Zhang \& Chen, 2015). The Gini coefficient is a broad index that applies in a global that describes income distribution level (Han et al., 2016). Han et al. (2016)suggest that the Gini coefficient is the most appropriate indicator for measuring social inequality, especially in a global context. The Gini coefficient is an aggregate income inequality measurement that provides robust and straightforward measures.

Ln Income Inequality is the natural logarithm of the Gini coefficient. The Income Inequality variable is transformed by natural 
logarithm to fulfill the normality assumptions because log transformation is useful for improving distributed positive skew and unequal variances. Gini coefficient is used to measure the extent of the income distribution (consumption expenditure) among individuals or households. The Lorenz curve plots the cumulative percentage of total revenue received on an aggregate number of recipients, beginning with the most miserable individual or family. The Gini coefficient measures the area between the Lorenz curve and a hypothetical line of absolute equality expressed as a maximum percentage of the area below the line (The World Bank, 2017). The Gini 0 coefficient represents perfect equality, where means everyone has the same income, while index 1 implies ideal inequality where means the entire profit is in one individual. The Gini coefficient is an aggregate income inequality measurement that provides robust and straightforward measures.

Unemployment is the total unemployment percentage of the full labor force (ILO estimated); unemployment refers to the part of the labor force whom not working but available and looking for a job. Inflation consumer price index (annual). Inflation measured by the consumer price index that reflects the percentage change in the yearly cost of the consumer to obtain a basket of goods and services that may change at specified intervals, Laspeyres formula is generally used (The World Bank, 2017).

School enrollment, tertiary (gross percentage). The total enrollment ratio to population (regardless of age), who formally enrolls tertiary education levels. Tertiary education, whether it meets or does not meet the advanced research qualifications, with a minimum requirement is the successful completion of secondary education. School enrollment tertiary is used to measure human capital with educational concepts (The World Bank, 2017).

Gross capital formation (percentage of GDP), gross capital formation (total domestic investment) consists of additional economic fixed assets plus net changes in inventory levels. Fixed assets include land improvements (fences, ditches, sewers), purchase of factories, machinery and equipment, and construction of roads, railways, schools, offices, hospitals, private residences, commercial, and industrial buildings. Inventories are goods inventories owned by a company to meet temporary and unpredictable fluctuations in production or sales, and "work in process." The acquisition of net goods is also considered capital formation (The World Bank, 2017).

Urban population (total percentage), urban population refers to people living in urban areas defined by the national statistical office - data collected by the United Nations Population Division (The World Bank, 2017).

GDP growth (annual percentage), the annual percentage rate of GDP growth at market prices based on local currency is constant. The aggregate base on the continuous US dollar of 2010. GDP is the sum of gross value added by all producers in the economy, plus product taxes and minus subsidies that are not including in product value. It is calculating without reducing depreciation of fabrication assets or depletion and degradation of natural resources (The World Bank, 2017).

The general government final expenditure (percentage of GDP), general government final expenditure (general government consumption) includes all government purchases of goods and services (including employee compensation). It also covers expenses for national defense and security but excludes government military expenditures that are part of government capital formation (The World Bank, 2017).

The research data are taking from the World Bank databank. The research model then analyzed using Prais-Winsten with a robust approach to estimate seven independent variables on income inequality as the dependent variable. Then the regression model was tested with diagnostic tests to prove that the regression model passed all classic assumption tests.

\section{Results and Discussion}

3.1 Results

The statistical results of the model in Table 1 show that only the human capital variable is significant with confidence levels above $95 \%$, while 
the unemployment, inflation, physical capital, urbanization, GDP growth, and government expenditure are not significant. Human capital negatively affects the Gini coefficient, so that income distribution will be favorable. That an increase in human capital can make income distribution more equitable. This result is similar to the previous study of Shahpari and Davoudi (2014) in which human capital will reduce income inequality.

While unemployment, inflation, physical capital, urbanization, GDP growth, and government expenditure do not affect income inequality. This relationship is in contrast to previous studies (Zhang \& Chen, 2015), where urbanization will shorten inequality in the short-term and widen disparities in the long run; instead, government expenditure will widen inequality in short and reduce inequities in the long term. (Shahpari \& Davoudi, 2014)In the long run, the increase in unemployment, inflation, GDP growth can make income distribution uneven while increasing physical capital will make income distribution more evenly in the long term (Shahpari \& Davoudi, 2014).

The R2 value 0.986 indicates seven independent variables selection explaining income inequality variable variation by 98.6 percent, the remaining 1.4 percent determined by other variables outside the model. This decision is acceptable if the $\mathrm{F}$ test shows a significant value. In this model, the $\mathrm{F}$ value is 2.570 and significant at a $5 \%$ significance level, so it can conclude that this regression model is suitable and statistically significant.

The diagnostic test results are presented in Table 2. Robust treatment will automatically eliminate heteroscedasticity by robustly weighing standard errors. The regressions model, after robust treatment, has been determined to be free of heteroscedasticity. Prais-Winsten treatment will automatically remove autocorrelation. By adding the autoregression variable with the specified lag. The regression model after Prais-Winsten treatment has been determined to be free of autocorrelation. Therefore, this model can eliminate symptoms of heteroscedasticity and autocorrelation with robust and Prais-Winsten. Then the Mean VIF Multicollinearity value is not greater than 10; it can say that the model meets the assumption of non-multicollinearity. The next model fulfills the normality assumption because the combined K-S value from the One-Sample Kolmogorov-Smirnov Test is more than the significance value of 0.05 . So the regression model with Prais-Winsten with the robust method used already meets BLUE (Best Linear Unbiased Estimator) assumption in estimating interval and testing population regression parameters.

Table 1. Prais-Winsten with Robust Regression

\begin{tabular}{|c|c|c|c|c|}
\hline \multicolumn{5}{|c|}{ Dependent Variable: Ln Income Inequality } \\
\hline $\begin{array}{c}\text { Independent } \\
\text { Variables }\end{array}$ & Coefficients & $\begin{array}{c}\text { Semi Robust } \\
\text { Standard Error }\end{array}$ & $\mathbf{t}$ & $P>(t)$ \\
\hline Unemployment & 0.002 & 0.004 & 0.470 & 0.639 \\
\hline Human Capital & -0.004 & 0.001 & -3.780 & 0.000 \\
\hline Inflation & 0.000 & 0.000 & 0.490 & 0.622 \\
\hline Physical Capital & 0.001 & 0.001 & 1.130 & 0.260 \\
\hline Urbanization & 0.000 & 0.001 & 0.230 & 0.816 \\
\hline GDP Growth & -0.0001 & 0.001 & -0.820 & 0.411 \\
\hline $\begin{array}{l}\text { Fiscal } \\
\text { Expenditure }\end{array}$ & 0.002 & 0.004 & 0.610 & 0.5400 \\
\hline $\mathrm{R}^{2}$ & \multicolumn{4}{|c|}{0.986} \\
\hline $\mathrm{F}(7,162)$ & \multicolumn{4}{|c|}{2.570} \\
\hline Probability $>F$ & \multicolumn{4}{|c|}{0.015} \\
\hline $\begin{array}{l}\text { Number of } \\
\text { observations }\end{array}$ & \multicolumn{4}{|c|}{170} \\
\hline
\end{tabular}


Table 2. Diagnostic Test

\begin{tabular}{|c|c|c|c|c|}
\hline Test Name & Value & $\begin{array}{c}\text { Result Before } \\
\text { Treatment }\end{array}$ & Treatment & $\begin{array}{l}\text { Effect After } \\
\text { Treatment }\end{array}$ \\
\hline $\begin{array}{l}\text { Wooldridge Test For } \\
\text { Autocorrelation }\end{array}$ & 0.034 & Autocorrelation & $\begin{array}{l}\text { Prais- } \\
\text { Winsten }\end{array}$ & No autocorrelation \\
\hline $\begin{array}{l}\text { Breusch-Pagan / Cook- } \\
\text { Weisberg Test for } \\
\text { Heteroscedasticity }\end{array}$ & 0.000 & Heteroscedasticity & Robust & Homoscedasticity \\
\hline $\begin{array}{l}\text { Mean VIF } \\
\text { Multicollinearity }\end{array}$ & 1.330 & Non-multicollinearity & - & Non multicollinearity \\
\hline $\begin{array}{l}\text { One-Sample } \\
\text { Kolmogorov } \\
\text { Smirnov Test } \\
\text { against Theoretical } \\
\text { Distribution Normal } \\
\text { (Combined K-S) }\end{array}$ & 0.456 & Normal & - & Normal \\
\hline
\end{tabular}

\subsection{Discussion}

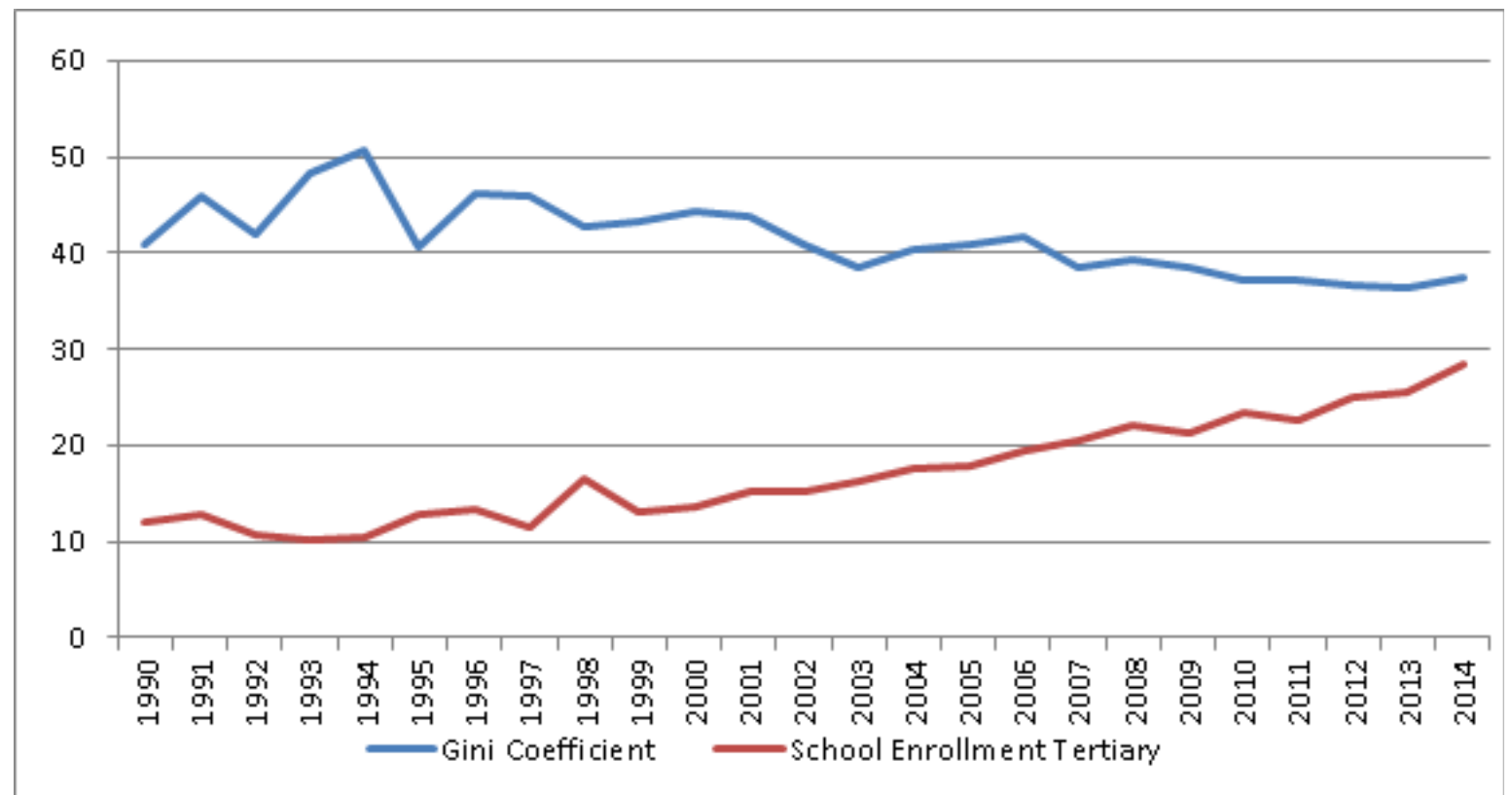

Figure 1. Gini Coefficients and School Enrollment Tertiary in 52 Lower Middle Income Countries 1990-2014

Gini coefficient trend changes in 52 Lower Middle-Income Countries in Figure 1. The Gini coefficient peaked to its highest point of 0.506 in 1994. Then it began to decline to the lowest point of 0.364 in 2013 , but it rose again to 0.375 in 2014 . However, the Gini coefficient is still below the warning line inequality of 0.400 .

The income inequality situation looks bad in mid-year of ninety, as illustrated by historical indicators. There are several experiments for the reconstitution of an educational system aimed at providing equal opportunities in education for all people by realizing human capital to help increase lifetime income and raise standards of living people in the country. This experiment explains the role of human capital investment undertaken by the government, income inequality in the early stages of development widened due to 
initial endowment and level of social investment (Fakthong, 2012).

Tertiary school enrollment declined to $10.275 \%$ in 1993 , the decline in school enrollment tertiary allegedly leading to higher Gini coefficients in 1994. Then tertiary school enrollment continues to increase up to $28.378 \%$ in 2014, improving school enrollment tertiary make the Gini coefficient fell below the warning line 0.400 in 2014. The declining trend of the Gini coefficient from 1994 to 2013 reflects the government's policy on decreasing income inequality is quite useful.

However, educational placement and research \& development investment will increase the average rate of human capital accumulation in the economy by utilizing human capital accumulation and accelerating the convergence of income. Therefore, long-term budgets for social capital investments should grow more and stimulate the economy to achieve a new higher steady-state in the next generation (Fakthong, 2012). This result is similar to the previous study of Castello \& Domenech (2002); Coleman (1968); Heckman (2005), in which human capital will reduce income inequality.

\section{Conclusions}

In the estimated model, the results show an increase in human capital (percentage of school enrollment tertiary) can make income distribution more equitable in the long run. Therefore, encouraging tertiary school enrollment can be a way to achieve an equal income distribution. The policy implications, authors, suggest human capital with a proxy of tertiary school enrollment should be improved to reduce income inequalities in lower-middle-income countries. Primarily, human capital investment should allocate to those most in need; that is, the poor to increase their chances of getting jobs; this will make a significant contribution to income growth and minimize income inequality.

\section{Acknowledgement}

This research is supporting by Kementerian Riset, Teknologi, dan Pendidikan Tinggi Republik Indonesia, and we thank "anonymous" reviewers for their so-called insights.

\section{REFERENCES}

Bagliano, F. C., \& Bertola, G. (2005). Models for Dynamic Macroeconomics. In Models for Dynamic Macroeconomics. https://doi. org/10.1093/0199266824.001.0001

Berg, A., \& Ostry, J. (2011). Inequality and Unsustainable Growth: Two Sides of the Same Coin? International Monetary Fund Staff Discussion Note, 1-21. https://doi. org/10.1017/CBO9781107415324.004

Blinder, A. S., \& Esaki, H. Y. (1978). Macroeconomic Activity and Income Distribution in the Postwar United States. The Review of Economics and Statistics. https://doi.org/10.2307/1924254

Bourguignon, F., \& Morrisson, C. (1998). Inequality and development: The role of dualism. Journal of Development Economics, 57(2), 233-257. https://doi. org/10.1016/S0304-3878(98)00089-3

Buse, A. (1982). The Cyclical Behaviour of the Size Distribution of Income in Canada: 194778. The Canadian Journal of Economics. https://doi.org/10.2307/134775

Bussolo, M., De Hoyos, R. E., Medvedev, D., \& van der Mensbrugghe, D. (2010). Global Growth and Distribution: Are China and India Reshaping the World? In Southern Engines of Global Growth (pp. 77-113). https://doi.org/10.1093/ acprof:oso/9780199580606.003.0005

Castello, A., \& Domenech, R. (2002). Human Capital Inequality and Economic Growth: Some New Evidence. The Economic Journal, 112(478), C187-C200. https://doi. org/10.1111/1468-0297.00024

Chaudhuri, S., \& Ravallion, M. (2007). Partially Awakened Giants Uneven Growth in 
Jurnal Ekonomi Pembangunan: Kajian Masalah Ekonomi dan Pembangunan, 20 (2), 2019, 222-231

China and India. Dancing with Giants: China, India, and the Global Economy, 175-210. https://doi.org/10.1017/ S147474560800387X

Checchi, D. (2004). Does Educational Achievement Help Explain Income Inequality? In Inequality Growth and Poverty in an Era of Liberalization and Globalization. https:// doi.org/10.1093/0199271410.003.0004

Coleman, J. S. (1968). Equality of Educational Opportunity (COLEMAN) Study (EEOS). Equity \& Excellence in Education, 6(5), 19-28. https://doi.org/10.3886/ICPSR06389

De Gregorio, J., \& Lee, J.-W. (2002). Education and income inequality: new evidence from cross-country data. Review of Income and Wealth, 48(3), 395-416. https://doi. org/10.1111/1475-4991.00060

Fakthong, T. (2012). Convergence in Income Inequality and Growth under Public Investment in Human Capital: The Case of Thailand. Procedia Economics and Finance, 2(Qqe), 315-324. https://doi.org/10.1016/ S2212-5671(12)00093-7

Han, J., Zhao, Q., \& Zhang, M. (2016). China's income inequality in the global context. Perspectives in Science, 7, 24-29. https:// doi.org/10.1016/j.pisc.2015.11.006

Heckman, J. (2005). Inequality in America: What role for human capital policies? Focus, 23(November 2004), 10. https://doi. org/10.1007/s10888-006-9028-6

Kudasheva, T., Kunitsa, S., \& Mukhamediyev, B. (2015). Effects of Access to Education and Information-communication Technology on Income Inequality In Kazakhstan. Procedia - Social and Behavioral Sciences, 191, 940-947. https://doi.org/10.1016/j. sbspro.2015.04.459

Kuznets, S. (1955). Economic growth and income inequality. The American Economic Review, 45(1), 1-28. https://doi.org/10.2307/2118443

Ling, S. C., Osman, A., Muhammad, S., Yeng,
S. K., \& Jin, L. Y. (2016). Goods and Services Tax (GST) Compliance among Malaysian Consumers: The Influence of Price, Government Subsidies and Income Inequality. Procedia Economics and Finance. $\quad$ https://doi.org/10.1016/s22125671(16)00025-3

Lundberg, M., \& Squire, L. (2003). The simultaneous evolution of growth and inequality. Economic Journal, 113(487), 326-344. https://doi.org/10.1111/14680297.00127

Mihnenoka, A., \& Senfelde, M. (2015). Wage Share as a Factor of Income Inequality in the Context of the Structure of National Economy. Procedia Economics and Finance, 26(15), 1035-1043. https://doi.org/10.1016/ S2212-5671(15)00927-2

Militaru, E., \& Stanila, L. (2015). Income Variability in Romania: Decomposing Income Inequality by Household Characteristics. Procedia Economics and Finance, 26(15), 227-233. https://doi. org/10.1016/S2212-5671(15)00823-0

Mincer, J. (1958). Investment in Human Capital and Personal Income Distribution. The Journal of Political Economy, 66(4), 281302. https://doi.org/10.1086/521238

Muellbauer, J., \& Atkinson, A. B. (1976). The Economics of Inequality. Economica. https://doi.org/10.2307/2553144

Nolan, B. (1986). Unemployment and the Size Distribution of Income. Economica. https:// doi.org/10.2307/2554095

Nolan, B., Salverda, W., \& Smeeding, T. M. (2012). The Oxford Handbook of Economic Inequality. In The Oxford Handbook of Economic Inequality. https://doi.org/10.1093/ oxfordhb/9780199606061.001.0001

OECD. (2013). Divided we stand. Why inequality keeps rising. Journal of Chemical Information and Modeling, 
53, 1689-1699. https://doi.org/10.1017/ CBO9781107415324.004

Qin, D., Cagas, M. A., Ducanes, G., He, X., Liu, R., \& Liu, S. (2009). Effects of income inequality on China's economic growth. Journal of Policy Modeling, 31(1), 69-86. https://doi. org/10.1016/j.jpolmod.2008.08.003

Ravallion, M. (2004). Competing Concepts of Inequality in the Globalization Debate. Brookings Trade Forum. https://doi. org/10.1353/btf.2005.0012

Ravallion, M., \& Chen, S. (2003). Measuring pro-poor growth. Economics Letters, 78(1), 93-99. https://doi.org/10.1016/S01651765(02)00205-7

Shahpari, G., \& Davoudi, P. (2014). Studying Effects of Human Capital on Income Inequality in Iran. Procedia - Social and Behavioral Sciences, 109, 1386-1389. https://doi.org/10.1016/j.sbspro.2013.12.641

Smeeding, T. M., \& Weinberg, D. H. (2001). Toward a uniform definition of household income. Review of Income and Wealth, 47(1), 1-24. https://doi.org/10.1111/14754991.00001

Stiglitz, J. E. (2015). The Price of Inequality: How Today's Divided Society Endangers Our Future. 379-399. https://doi.org/10.7916/ D8-96ED-6058

The World Bank. (2017). Data: The World Bank Group. Retrieved January 19, 2017, from http://data.worldbank.org/

Welch, F. (1999). In defense of inequality. American Economic Review, 89(2), 1-17. https://doi.org/10.1257/aer.89.2.1

Wroblowský, T., \& Yin, H. (2016). Income inequalities in China: Stylized facts vs. reality. Perspectives in Science. https://doi. org/10.1016/j.pisc.2015.11.011

Zhang, Q., \& Chen, R. (2015). Financial development and income inequality in China: An application of SVAR approach.
Procedia Computer Science, 55, 774-781. https://doi.org/10.1016/j.procs.2015.07.159 